\title{
АМБІВАЛЕНТНА РОЛЬ АКУЛЬТУРАЦІЇ В УКРАЇНСЬКОМУ СОЦІУМІ
}

\section{Березінська О. В.}

\section{ВСТУП}

На початку XXI століття проблема міжкультурних контактів i $і$ х наслідків стимулювала інтерес культурологів до вивчення природи міжетнічної взаємодії. Стало важливим звернути увагу на можливість проживання культурно-різних груп в одній державі на рівних правах, без взаємних образ, зіткнень, претензій на домінування, на визначення факторів, що лежать в основі толерантної міжетнічної взаємодії та взаємосприйняття.

Кожна культура - це мікровсесвіт, вона не ізольована. Жодна людина не може жити без взаємин з іншими людьми, жоден народ не може жити в ізоляції від іншого. Для функціонування індивідуума культура дуже важлива. Вона зміцнюе солідарність між людьми i сприяє взаєморозумінню. Тому сьогодні інтерес викликає не тільки питання про особливості окремого етносу, а й проблеми взаємодії різних культур.

Актуальність проведеного дослідження зумовлена небувалою міграцією останніми роками; соціальними, політичними та економічними змінами у світовому масштабі, їх змішанням і зіткненням. Культурні бар'єри стираються в результаті різних міжкультурних контактів: туризм, спорт, військова співпраця, ділові й особисті зв'язки тощо. Межі між «своїми» і «чужими» зникають. Зміни, що виникають при цьому, охоплюють практично всі форми життя й отримують у різних культурах неоднозначну оцінку. Ці сприйняття найчастіше визначаються особливостями взаємодіючих культур. Тенденція культурної глобалізації особливо загострює інтерес до культурної самобутності. Культурне розмаїття сучасних народів збільшується, i кожен iз них прагне зберегти й розвинути свою цілісність і зберегти неповторний культурний вигляд.

Сучасні міграційні процеси відіграють важливу роль у формуванні міжетнічних відносин у полікультурному суспільстві. Будь-яка розвинена культура включає в себе дві утворюючі підсистеми - ядро культури й захисний пояс. У ядро культури входять специфічні для цього етносу процеси, події та явища, які відрізняють його від інших. До таких належать мова, фундаментальні естетичні та етичні цінності, монументальні споруди й пам'ятники, основні правила й норми поведінки в суспільстві, стійкі стандарти сімейної та побутової поведінки, типові форми образотворчого мистецтва, музичної творчості 
тощо. Ядро культури цього соціуму зазвичай зберігає самоідентичність протягом багатьох століть, а іноді й тисячоліть ${ }^{1}$. Сутність захисного поясу - у гарантованій перешкоді проникненню сторонніх норм i стандартів у ядро своєї культури протягом нетривалих інтервалів історичного часу.

Ареальне вивчення барвистої палітри етнічних культур є одним із найважливіших науково-дослідних завдань. Актуальними стають проблеми розвитку й функціонування сучасних етнокультур, які вчинили різкий перехід від традиційно-етнічного до цивілізаційного рівня. Структура культурного життя являє собою своєрідну тріаду. Поперше, це загальнонаціональна культура як частина світової культури. По-друге, це змішана культура, яка народжується в національних утвореннях на основі взаємодії представників різних соціальних верств. По-третє, це етнокультура, що живе на певній території. В етнографічному плані культурне світове співтовариство являє неоднорідне утворення, що складається 3 окремих соціокультурних утворень зі своїми життєвими укладами, менталітетом і самосвідомістю, з різними соціально-економічними й культурними рівнями розвитку.

Важливо звернути увагу на те, що між різними культурами існують, реалізуються й видозмінюються різноманітні відношення, виникають $\mathrm{i}$ зникають несхожі, часто амбівалентні процеси, що призводять до модифікацій культур, а іноді й до їх повного зникнення. Останній процес часто відбувається в результаті історично зумовлених соціальноекономічних і прямих військових зіткнень. Одним із таких процесів $\epsilon$ акультурація, що яскраво виражена в сучасних умовах.

Акультурація являе собою досить складний процес проникнення одних культур, культурних цінностей, естетичних, моральних, побутових норм і видів діяльності в інші культури. При цьому певні, більш розвинені, більш «сильні» культури можуть значно трансформувати й видозмінювати більш «слабкі» культури.

На початку XXI ст. суспільство досягло декількох рівнів структурування: цивілізації, нації, етноси й держави, причому етнос рідко збігається 3 нацією, а держава - із цивілізацією. Основна відмінність сучасних цивілізацій від раніше існуючих полягає в їх жорсткому взаємозв'язку, а отже, і взаємовпливі, взаємозалежності на глобальному рівні. Це пояснюється наявністю декількох факторів: збільшенням чисельності населення, посиленням комунікаційних процесів, розширенням засобів впливу на суспільство як усередині конкретної соціальної системи, так і за ії межами завдяки технічному прогресу.

\footnotetext{
${ }^{1}$ Ракитов А.И. Культура, цивилизация и современные технологи в перспективе глобальных трансформаций. Журнальный клуб «Интелрос». Век глобализащии. 2018. № 3. С. 55. 
У цьому контексті сучасний етнолог С.В. Лур'є дає таке визначення етносу: «Етнос - це соціальна спільність, якій притаманні специфічні моделі, що обумовлюють характер активності людини у світі, і яка функціонує відповідно до особливих закономірностей, спрямованих на підтримку унікального для кожного суспільства протягом тривалого часу, включаючи періоди великих соціокультурних змін» ${ }^{2}$. У цьому значенні С.В. Лур'є розглядав етнологічну культуру як структуру, що скріплює це суспільство й захищає його від розпаду.

Для етносів, які проживають в Одеському регіоні, процес взаємодії особливо примітний та органічний, бо близькі й споріднені їхні кореневі історичні витоки, гнучкі національні кордони. У цьому контексті можна виділити такі об'єднувальні елементи: мова, фольклор, релігія, звичаї, традиції, обряди.

У деяких теоретиків існує ідея «застарілості» національних цінностей. На XVII Всесвітньому філософському конгресі (Канада, 1983 р.), присвяченому філософським проблемам культури, західні теоретики розвивали тезу про несумісність сучасних динамічних процесів зі збереженням національних надбань. Висувалася теза про космополітизм глобальних процесів, що пов'язаний із байдужістю до унікальності національних культур ${ }^{3}$.

Глобалізаційні процеси в культурі збільшують роль акультурації як елемента міжкультурної взаємодії. Коли зустрічаються представники двох різних культур, то вони, маючи намір знайти спільну мову, намагаються зрозуміти один одного. Отже, акультурація пропонує навчання норм іншої культури, знайомство з її історичною спадщиною дає змогу знайти ефективну технологію спілкування людей. Це збагачує культури. У кожній із них $\epsilon$ елементи, запозичені з інших культур. I це може мати характер не тільки уніфікації або синтезу культур, а й характер процесу збільшення нового знання, адаптації цього знання й навіть прогресивної трансформації національної культури.

Зважаючи на те що змінився механізм акультурації, на багатоаспектність цього поняття, необхідно переосмислити його сутність і складники, що його формують.

\section{1. Підходи до трактування поняття «акультурація»}

Акультурація є об'єктом дослідження багатьох наук, проте досі немає єдиного підходу до трактування цього поняття.

Наприкінці XX - на початку XXI століть тема глобалізації вийшла на перший план суспільної свідомості. Глобалізація $\epsilon$ об’єктивною

\footnotetext{
2 Лурье С. Историческая этнология : учебное пособие. Москва : Гаудеамус, 2004. 624 с.

Солонська Н., Борисович Г. Українська канадіана : анотований покажчик видань 3 фонду Національної бібліотеки України імені В.І. Вернадського / наук. ред. Г.І. Ковальчук ; НАН України, Нац. б-ка України ім. В.I. Вернадського. Київ, 2017. 176 с.
} 
закономірністю розвитку суспільства й усього людства, формування в майбутньому єдиної взаємопов'язаної світової спільноти. Ще в 1949 р. німецький філософ К. Ясперс висунув ідею про «глобальне єднання», «єдине людство», «єдину долю народів», «створення цілісного планетарного світу людей» ${ }^{4}$. Основна увага акцентувалася на вплив «домінуючої» культури на «підпорядковану»; через роки предметом дослідження став зворотний вплив (наприклад, африканських музичних форм на сучасну західну музику, що виявилося, зокрема, у появі джазу, або вплив африканської скульптури й масок на живопис XX століття, що проявилося у творчості П. Пікассо). Явне або неявне ототожнення акультурації 3 асиміляцією поступилося місцем більш широкому розумінню акультурації як процесу взаємодії культур, у ході якого відбувається їх зміна, засвоєння ними нових елементів, утворення в результаті змішування різних культурних традицій принципово нового культурного синтезу.

Дослідження у сфері акультурації особливо інтенсифікувалися в перші десятиліття XXI століття. Це пов'язано зі справжнім міграційним бумом, який переживає людство та який проявляється в зростаючих процесах обміну студентами, фахівцями, а також у масових переселеннях. Згідно 3 новими глобальними статистичними даними $\mathrm{OOH}$, сьогодні у світі поза межами країни свого походження проживає понад 232 млн чоловік.

Ще недавно дослідники вважали, що найкращою стратегією акультурації $є$ повна асиміляція з домінуючою культурою. Але під час взаємодії культури не тільки доповнюють одна одну, а й вступають у складні відносини, виявляючи свою самобутність і специфіку. При цьому виявляються як позитивні слідства (збагачення культур), так i негативні (іх придушення, збіднення-ерозія). Ерозії зазвичай піддаються ті етнічні культури, які відчувають масований вплив ззовні й не мають достатньо розвинутої та стійкої культурної системи, здатної протистояти культурній експансії та адекватно відповідати новим життєвим вимогам.

Акультурація як елемент міжкультурної взаємодії $\epsilon$ історично мінливим процесом, який залежить від численних факторів. Зараз поняття «акультурація» набуває ширшого тлумачення. Акультурація видозмінюється та проявляється у вигляді різних модусів: бікультуралізм, полікультуралізм, мультикультуралізм, транскультуралізм тощо. Отже, акультурація відіграє прогресивну роль у глобальному суспільстві. Вона передбачає навчання норм іншої культури, знайомство з іiї історичною спадщиною, дає змогу знайти ефективну технологію спілкування індивідів.

Приклади акультурації досить численні в сучасному світі. Цьому сприяє багаторазове збільшення потоків міграції з одних регіонів в інші.

\footnotetext{
${ }^{4}$ Ясперс К. Смысл и назначение истории. Москва : Политиздат, 1991. 527 с.
} 
Так, шлях акультурації проходили всі розділені народи, території розселення яких розділені державними кордонами, які змушені пристосовуватися до умов культурно-мовного середовища, створеного більшістю, що їх оточує. Такі народи мають ареали проживання у двох або більше країнах, причому населення різних ареалів має між собою більш або менш регулярні контакти. До розділених народів можна зарахувати, наприклад, уйгурів, які проживають у СиньцзянУйгурському автономному районі КНР, іранських азербайджанців, секей та угорців у Румунії, латиноамериканців у США (особливо в Маямі); в Україні - кримських татар. Прагнення розділених народів возз'єднатися зачіпає інтереси різних держав, у результаті чого проблематично реалізується та загрожує конфліктами. При цьому тривала акультурація 3 тих чи інших причин не завершується асиміляцією й може мати прихований конфліктний потенціал. 3 іншого боку, над багатьма народами (особливо діаспорами), що успішно пройшли шлях акультурації, нависає загроза повної асиміляції (греки-фанаріоти в Османській імперії, франко-онтарці та франко-манітобці в Канаді). Ураховуючи підходи науковців, ми розглядаємо діаспору як частину етносу, що проживає поза межами історичної батьківщини внаслідок суб'єктивних та об'єктивних обставин, зберігає етнічну самобутність і мову, прямо чи опосередковано підтримує зв'язок із країною походження. У контексті діаспори поняття «українська діаспора» базується на визнанні кордонів України як політичної реальності, факті проживання українців в інших державах ${ }^{5}$.

Разом із поняттям «акультурація» уживають поняття «інтеграція»найбільш краща установка акультурації. Однак далеко не завжди члени недомінуючої групи вільні у виборі цієї стратегії. Домінуюча група може обмежити вибір або змусити до інших форм акультурації, наприклад, до сепарації. У цьому разі позитивній етнічній ідентичності відповідає інтолерантність. Якщо сепарація має вимушений характер виникає в результаті дискримінаційних дій домінуючої більшості, тоді вона перетворюється на сегрегацію. Недомінуюча група може вибрати асиміляцію, що свідчить про готовність прийняти ідею «плавильного котла» культур ${ }^{6}$. Варто зазначити, що відповідати асиміляції буде негативна етнічна ідентичність та етнічна толерантність. Вельми рідко група меншості обирає маргіналізацію, якій притаманна негативна етнічна ідентичність та інтолерантність. Маргіналами стають у результаті спроб поєднувати насильницьку асиміляцію з насильницькою сегрегацією.

Розглянемо амбівалентну роль акультурації в цих умовах і її роль у найближчому майбутньому. Захід показав усьому світу, що таке

\footnotetext{
5 Трощинський В. Українці у світі. Київ : Альтернативи, 1999. С. 19-24.

${ }^{6}$ Park R. Race and Culture. New York, 1950. C. 102.
} 
модернізація, чого може домогтися суспільство в галузі освіти, науки, техніки, індустріалізації. Саме Захід першим зіткнувся з проблемою виснаження природних ресурсів, що може загрожувати загибеллю людству. Суспільство виявилося перед дилемою: або нічим не обмежені новації, швидкі темпи прогресивного розвитку, або баланс із навколишнім середовищем і різке уповільнення темпів технічного прогресу, бо природа не встигає адаптуватися до нововведень, а це загрожує людству загибеллю.

Повноцінне здійснення міжкультурного й міжконфесійного діалогу передбачає всебічне залучення представників різних культурних спільнот - культурно-історичних, етноконфесійних, локальнорегіональних, етнолінгвістичних, які вивчають духовний світ, традиції, історію і культуру людей, сформованих не тільки у власній культурній традиції, а й в умовах інокультурного досвіду. Це утворення акцентує увагу на накладення світоглядних, ідеологічних, етичних і релігійних систем, на взаємовплив різних рівнів і форм ідентичності, на специфіку культурних інтересів різних спільнот. Відповідно, актуалізується теоретичний інтерес до етнічної, регіональної, локальної специфіки культур, моделі взаємодії окремих регіонів України. 3 іншого боку, виникає потреба інтегрувати знання про особливості менталітету, соціокультурного буття і свідомості націй, етносів, етнографічних груп і культурних регіонів України в систему специфічних концептів, категорій і понять.

Вищезазначені критерії безпосередньо впливають на динаміку новацій у конкретно-історичних умовах, на зміну ціннісних орієнтацій, які залежать від інноваційної діяльності соціуму як відповідних дій. Із поняттям «акультурація» тісно пов'язане поняття «етнічна меншина». Це група, яка кількісно менша щодо іншого населення держави й не має номінованого становища в ній, члени якої - громадяни цієї країни мають низку етнічних, релігійних або лінгвістичних особливостей, що відрізняє їх від іншого населення, і мають почуття солідарності, спрямоване на збереження своєї культури, традицій, релігії та мови.

Традиції - це елементи культурної спадщини, що передаються i зберігаються від покоління до покоління протягом тривалого часу. Як традиції можуть виступати певні суспільні установки, норми поведінки, цінності, ідеї, звичаї, обряди тощо.

Інновації - це будь-які відкриття, які здійснюються на індивідуальноособистісному рівні, нові явища, усвідомлені людиною, це щось зовсім нове в конкретній ситуації, у конкретному суспільстві. Інновації живуть тільки за умови їх передання, інакше новація вмирає разом із групою, що iї прийняла. Середовище трансляції має вагоме значення для загального перебігу подій в етносі, культурі. У цьому разі вона впливає 
лише на етнос або субетнос, певний соціальний шар. Самі новації зумовлені культурно-історичним світом, середовищем, у якому живе й працює людина, культурними традиціями, які окреслюють та обмежують проблемне поле руху думки, кордони й цілі можливих нововведень. Нове часто виступає на поле індивідуальної свідомості як наслідок складного культурно-історичного або соціокультурного світу людини (громадського діяча, соціального реформатора, вченого). Тому дуже часто в соціальних новаціях велику роль відіграють етнокультурні маргінали. На громадському рівні новація виступає як «трансверсія» культурних естафет, традицій, як перетворення через власний код культури чужорідних впливів. Принципово нову культурну традицію, новий культурний синтез дає новий етнос, що сформувався на базі мінімум двох етнічних систем, які розпалися. Леслі А. Уайт позначив культурний процес як «безліч взаємодіючих культурних елементів вірування, звичаї»; це взаємодія «змагальна, оскільки ії елементи можуть застарівати й виходити із загального потоку; у процес включаються нові елементи, і створюються нові комбінації й синтези відкриття та винаходи культурних елементів» 7 .

В умовах стрімко мінливого світу потреба у швидкому формуванні ідентичності в сучасних суспільствах актуалізує, посилює та переформулює минулі травми й несправедливість у відносинах між спільнотами, які можна охарактеризувати як зіткнення культур. У цьому сенсі можна говорити, що ідея Семюела Хантінгтона про «зіткнення цивілізацій» правильна. За словами відомого американського соціолога й політолога, вигляд світу все більше залежить від відносин між цивілізаціями: «У народжуваному світі основним джерелом конфліктів буде вже не ідеологія й не економіка. Найважливіші кордони, що розділяють людство, і переважні джерела конфліктів будуть визначатися культурою. Нація-держава залишиться головною дійовою особою в міжнародних справах, але найбільш значущі конфлікти глобальної політики будуть розгортатися між націями та групами, що належать до різних цивілізацій» ${ }^{8}$.

Отже, суспільство в наш час поставлено перед дилемою: залишатися традиційним і капсулюватися, щоб зберегти свою ідентичність, або ставати сучасним та інтегруватися в загальнолюдську культуру. Особливий інтерес сьогодні становить вивчення етнічної самосвідомості людей у таких регіонах України, де проживають українці, болгари, молдавани, румуни, гагаузи та інші народи зі своєю традиційною культурою. Актуальним стає розгляд особливостей акультурації, поєднаних в одному геоісторичному просторі етносів зі світовим

\footnotetext{
${ }^{7}$ Уайт Л.А. Понятие культуры / пер. Е.М. Лазаревой. Антология исследований культуры / сост. С.Я. Левит. Санкт-Петербург : Университетская книга, 1997. Т. 1. С. 17-48.

${ }^{8}$ Хантингтон С. Столкновение цивилизаций. Москва : ООО «Издательство АСТ», 2003. С. 92.
} 
співтовариством і один із одним, в умовах традиційної міжетнічної взаємодії. Поряд із проблемами акультурації етносів у світовому співтоваристві як процесу й результату взаємовпливу національних культур постає проблема акультурації окремої людини.

\section{2. Концепція синергетичного підходу до дослідження глобального соціокультурного розвитку}

Колективний досвід епохи, який ще не знайшов вербальної визначеності, який ще не структурований і не канонізований, називають духом часу. Він сприймається учасниками соціальних дій інтуїтивно й володіє кооперативним ефектом під час формування загального настрою. Це особливий стан соціуму - стан його нестійкості, що характеризується чутливістю середовища до малих змін. Саме через нестійкість середовища здійснюється зв'язок рівня індивідуальної творчості, його відкриттів 3 рівнем соціальної спільноти, 3 його готовністю прийняти новації. «Саме в стані нестійкості відкритого нелінійного середовища малі флуктуації, випадковості призводять до становлення нової макроскопічної картини буття. Середовище, яке перебуває в стані нестійкості, може 3 нелінійного позитивного зворотного зв'язку, тобто багато разів, посилити ці малі обурення, флуктуації й розгорнути їх у вигляді нового упорядкованого стану» 9 .

Спосіб аналізу культури 3 позицій синергетики грунтується на взаємодії двох протилежних сил: перша створює структури, друга руйнує цю закономірність, відкриту в науковому пізнанні синергетикою ${ }^{10}$. Принципи, на яких грунтується синергетика, - нестійкість, нелінійність. За словами одного із засновників «філософії надій» I.P. Пригожина, синергетика пізнає порядок через хаос, через нестійкість і нерівновагу, які називає двигуном уперед ${ }^{11}$. Без нестабільності не бути прогресу. Випадкові флуктуації можуть вплинути на подальшу динаміку культури. Завдяки таким малоочікуваним культурним контактам відбувається запозичення досягнень інших народів.

Якщо в соціальному середовищі (будь-яке соціальне середовище нелінійне) під впливом одного або декількох факторів наростає неоднорідність, то таке соціальне середовище нестійке до малих збурень. Невелика група може принципово змінити ситуацію, якщо рівень розуміння запропонованих ними ідей у суспільстві зростає. Це створює умови для формування в суспільстві нової ідеологічної парадигми. Сама логіка розвитку суспільства призводить до певних новацій. Це відбувається тоді, коли існує особливий стан менталітету

\footnotetext{
${ }_{9}^{9}$ Князева Е.Н.. Эволюция, культура, познание. Москва, 1996. С. 78, 86.

${ }^{10}$ Шейко В.М., Богуцький Ю.П., Кушнаренко Н.М. Наукова творчість у галузі культурології і мистецтвознавства : навчальний посібник. Харків : ХДАК, 2016. С. 104.

11 Пригожин И., Стенгерс И. Время, хаос, квант. К решению парадокса времени. Москва : Прогресс, 1994.
} 
суспільства, чутливий до малих зрушень у вирішенні проблем, коли навіть малі зміни здатні розростися в нові колективні образи, обряди, традиції, світоглядні установки більшості людей. «Навіть малі відмінності в перевагах поводитися одним чином, а не іншим мають тенденцію експоненціально розростатися в такі, що сильно розрізняються, культурні зразки» ${ }^{12}$.

Онтологія соціальних відносин виражається в системі цінностей і рефлексує суспільною свідомістю. Нерозривність онтології та аксіології зумовлює створення механізму соціальної компенсації, коли переваги еліти перед іншою частиною суспільства врівноважуються важкими соціальними обов'язками, не властивими іншій частині суспільства. Найближчі соратники скіфського царя політично, а часто й фізично вмирали разом із царем, карфагеняни в період важких випробувань приносили в жертву «молохові» дітей еліти, вождь даків, відправляючи на війну свій народ, убивав власного сина. I таких прикладів величезна кількість. Форма соціальної компенсації змінювалася історично і значно відрізнялася між цивілізаціями - від жертви життям до жертви капіталом, коли високі податки 3 високих доходів супроводжуються виробленням механізму, що не допускає їх приховування, коли ідеологія перетворюється в жорсткий канон, а потім спрощується, вихолощується на догоду певним верствам, вона не витримує конкуренції з новою ідеологією, і неважливо, хто є суб'єктом нової ідеології: клас, каста, етнос. На рівні суб'єкта історичного процесу ми можемо констатувати наявність структурного розпаду або стан кризи, тої, що передує розпаду, якщо ситуація принципово не зміниться.

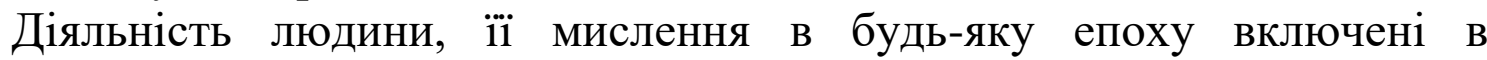
соціокультурну традицію етносу. Тому знищення сформованих традицій призводить до загибелі. 3 огляду на цей факт, величезне значення мають ідеології як системоутворювальний фактор етносу. Розвиток будь-якої ідеології, культури, соціальних інститутів має стадію не тільки еволюції, а й інволюції (деградації).

Варто зазначити, що ми вже змирилися 3 тим, що новий світ буде набагато жорсткішою системою. Пандемічна криза змусила зрозуміти, що світ складається не тільки 3 макроекономічних індикаторів та інструментів національної могутності держави. Глобальний світ - це ще й світ людей. Можливо, вийшовши 3 кризи 3 відносно невеликими людськими втратами, ми точно втратимо універсальну модель соціального розвитку й соціальної реалізації, яка дарувала нам останні тридцять років упевненість у завтрашньому дні. Пандемія коронавірусу вже зараз зламала не тільки економіку багатьох країн, а й комфортну для більшості модель соціокультурного розвитку. Культура занадто тісно,

\footnotetext{
${ }^{12}$ Князева Е.Н. Одиссея научного разума. Москва, 1995. С. 208.
} 
іноді нерозривно (як, наприклад, в Італії чи Франції) уписана в економічні процеси, так що будь-яка зміна економічної кон'юнктури призводить до неможливості жити «по-старому»: ходити в театри, ресторани й музеї, споживати візуальні образи професійного спорту й купувати рекламовані кінозірками та спортсменами товари.

Соціокультурна модернізація дійсно була «центральним процесором» глобалізації. Але навряд чи можна розраховувати на її незмінний вигляд після пандемії. Соціальні аспекти глобалізації сприймаються скоріше як свідчення самовпевненості людства. У контексті пережитих нами трансформацій варто виділити п'ять тенденцій соціальної глобалізації:

- інформаційне суспільство стало безальтернативним інструментом залучення в соціально-економічні процеси й засобом соціальної самоідентифікації;

- посткоронавірусний світ закріплює статус інформаційних інструментів як глобального зрівноважувача і глобального сегрегатора;

- при домінуванні мегаполісів як економічних платформ до їх домінування як формату середовища. Посткоронавірусний світ якщо не вб’є соціальне середовище мегаполісів, то змусить як мінімум переглянути небезпечне навіть i без коронавірусу судження, що мегаполіси - єдиний варіант забезпечити людству прийнятний соціальний стандарт. А культура, яка відображає процеси міської атомізації й деградації соціальних інститутів, - єдиний перспективний вид культури, доступний для «звичайної» людини;

- загострення й посилення домінування візуальних образів ідентифікації «свій - чужий»;

- перетворення географічної мобільності в соціальну нестійкість. Пандемія прискорить ці процеси, знявши необхідність дотримання традицій і ритуалів епохи, що іменувалася «інституційною демократією». Пандемія коронавірусу, імовірно, «обнулила» досягнення толерантності, залишить на їх місці вакуум особливо в країнах, що найбільш просунулися в цьому напрямі і зруйнували заради перемоги цінностей радикальної толерантності не тільки традиційні соціальні інститути, що відображали етнічні чи історичні ідентичності, а й культуру.

Світ може отримати соціально небезпечний варіант цифрового капіталізму, якщо вирішить, що йому немає альтернативи. Культура завжди була однією з головних парій глобалізації. Затиснута між шоубізнесом та елітарністю, вона була приречена, зберігаючи глобальність доступу, ставати все більш сегментованою за соціальними нішами. Головною проблемою було глибоке проникнення культури в економічний контекст, що включає в себе як мінімум три найважливіші обставини:

1. Космополітичність, причому англомовна, хоча неправильно ототожнювати ії тільки з американоцентричністю. 
2. Посередність до нижнього сегменту, оскільки його комерційне значення росло, що, імовірно, варто співвіднести не тільки з відмовою від «класичного» утворення, а й 3 утратою західною родовою аристократією статусу «головного замовника» у сфері культури.

3. Домінування принципу «максимізації охоплення», що означало домінування під час створення культурного твору у форматі, доступному максимально широкому колу «споживачів».

У сфері глобального соціокультурного розвитку виникала складна діалектика, яка не могла не завершитися кризою. 3 одного боку, високий ступінь убудованості культурного процесу в соціально-економічну систему передбачав спрощення культурного процесу, сегрегацію - 3 іншого. Поділ на «шоу-бізнес» і «справжню культуру» став не стільки соціальним, скільки майновим класифікатором, що не передбачав соціальної залученості, соціальної значущості.

Ситуація розвивалася за більш складною траєкторією, ніж протиставлення «віртуальна», точніше, віртуалізувана культура (і загалом соціокультурне середовище) для малозабезпеченої частини населення й більшої частини середнього класу й доступ до традиційної культури для верхньої частини середнього класу й такого, що звужується, прошарку багатих і надбагатих людей. Ця схема була відносно стрункою та поступово давала змогу перетворити класичну культуру в долю елітаріїв, залишаючи іншим верствам соціально залученого суспільства віртуалізовані сурогати реальних культурних артефактів.

3'явилася набагато більш складна й небезпечна для світу глобалізації конструкція соціальних моделей. 3 одного боку, розвивалася та зміцнювалася віртуальна культура «для бідних», побудована навколо максимального спрощення доступу до цифрових інтегрованим комунікацій, де горезвісна «вартість доступу» постійно знижувалася й скорочувалися цензурні обмеження.

3 іншого боку, соціокультурне середовище для еліти якщо й склалося, то не виявило себе до початку пандемії як повноцінна соціальна парадигма. Головним ідентифікатором належності до «еліти» була прихильність до глобальних «цінностей»: «гендерна рівність», «толерантність», «репрезентативна демократія», що не передбачала ніякого культурного наповнення, тільки поведінкове.

Помилково вважати, що пандемії коронавірусу вдасться зупинити динаміку трансформації соціокультурної сфери, яку вона придбала в період пізньої глобалізації. Занадто багато грошей і часу вкладено в те, щоб ці вектори сформувати, занадто серйозні комерційні перспективи відкривала соціокультурна сегрегація перед «глобальними інвесторами».

Особливість культури як сфери соціального розвитку полягала в тому, що культура як соціальна дія, яка складається 3 ритуалів, зразків та 
артефактів, у глобалізованому світі мала цілком визначене майбутнє, що вкладається у двійкову систему «культури для бідних» і культури елітарної з технологічним розшаруванням за типами каналів, задіяних у трансляції культурних артефактів. Розуміння культури все менше було пов'язано з естетикою й усе більше із цілком утилітарними факторами: можливістю доступу до певних технологій і наявністю ресурсів, щоб купувати той чи інший формат споживання культури. Ви могли купити тур у Париж і відвідати Лувр, а могли отримати віртуальний тур по Лувру за набагато менші гроші й у значно більш комфортному зі споживчого погляду форматі. Або отримати доступ до візуалізованого «домашнього» концерту кращих віртуозів скрипки й альта. I це вже не просто розшарування суспільства на бідних і багатих, це фіксація непереборності кордону в соціальному розшаруванні, формування двох різних і таких, що майже не перетинаються, моделей соціальної поведінки.

Цілком очевидними стають кілька паралельних сценаріїв, але в кожному 3 них культура й асоціювання тією чи іншою соціальною та національною групою себе 3 тим чи іншим типом поведінки щодо культурних артефактів стає найважливішим компонентом конкуренції моделей соціальної організації постпандемічних товариств.

Виникає досить очевидне запитання: чи може постпандемічна культура існувати поза каналів комунікації? У світі пізньої глобалізації феномен культури, якщо його розуміти як соціальну реальність, був невіддільний від комунікативних процесів і 3 синхронічної, i 3 діахронічної позиції. Але в постпандемічному світі постає питання, чи існує в принципі культура як феномен поза цифрового комунікаційного простору. I наскільки цифровий «зліпок» може замінити оригінал 3 емоційного погляду?

Що залишиться в глобальній культурі після пандемічної кризи? I чи залишиться вона як глобальний феномен, що об'єднує соціум, навіть розділений за класовим або релігійним принципом? Розуміння культури $\epsilon$ ключ до нового розуміння соціальних ідентифікацій і самоідентифікацій як на рівні окремої людини, так і на рівні соціальних груп. Можливо, виникнуть особливості соціального простору, де ключову роль відіграватимуть візуальні образи. Виникне простір для творчості й маніпуляцій, здатних підмінити творчість, і для конкуренції концепцій майбутнього.

Піонерами візуалізації стали кінотеатри, соціальна функція яких виявилася чи не першою жертвою пандемії. Але ми з вами спостерігаємо досить вдале паралельне існування офлайн- та онлайн-кінотеатрів. Тут найменша втрата ефекту комунікації. Концерти й театри - це контактний насамперед енергетично вид взаємодії з глядачами. Якщо кінотеатри в разі переходу в онлайн не втрачають ефекту комунікації, то театри й 
концерти однозначно втрачають, не кажучи вже про музеї, лекції, виставки. Кінематограф об'єктивно стане не просто найбільш важливим iз мистецтв, а й головним джерелом візуальних образів для подальшого копіювання та тиражування в соціальній поведінці. I тут у всій гостроті постає питання про лідерство: хто буде законодавцем візуальних трендів, той отримає серйозні бонуси в конкуренції соціальних моделей.

Висловимо кілька припущень, що великий європейський кінематограф буде страждати над втраченою «європейською мрією», занурюючись у кінематографічний стиль, подібний до того, що панував у європейській культурі між двома війнами. Або ми порівняно швидко побачимо нового європейського героя: Алена Делона, Адріано Челентано, Жан-Поля Бельмондо?

Де в цій сфері буде місце Україні? Адже без власних унікальних візуальних образів не варто брати участь у конкуренції за найбільш привабливу соціальну модель розвитку.

Постглобальність несе за собою віртуалізацію культури, і цінність матеріальних артефактів девальвується. Віртуалізація культури стає інструментом соціальної сегрегації. Вона визначає культурну спадкоємність, де головним соціальним «героєм» буде людина без власності, коренів. Це буде вічний кочівник інформаційного простору, що переміщується від «проекту» до «проекту», але не розуміє, що саме його життя $\epsilon$ проект зі своїм «початком» і «кінцем».

Освіта $є$ частиною культури. Але чи буде вона частиною нової віртуальної культури? Коронавірус дасть поштовх розвитку дистанційних i віртуальних методів освіти. Але чи буде це класична освіта в постпандемічному світі, або ми йдемо до «легокомпетенцій», що підбираються кожною людиною під свої поточні потреби? I чи залишиться «наукова й культурна спадкоємність», класична освіта й класична культура?

А головне питання: погодиться людство споживати лише віртуальні зліпки культури та соціальних благ або ж зажадає від глобальної еліти своєї частки в постпандемічній реальності?

Сенс зазначеного вище протиставлення розкривається порівняно просто: питання про соціокультурний розвиток постпандемічного світу $\epsilon$ елементом розвитку нової глобальної соціальної моделі, яка здатна бути більш гнучкою i зможе бути сприйнята більшістю глобалізованого раніше соціуму. Соціальні «скріпи» глобалізації зможуть почати відновлюватися раніше, ніж економічна глобальність. Можливо, саме розуміння місця культури в постпандемічному суспільстві допоможе вказати, у якому ми зараз місці.

Резюмуючи вищесказане, підкреслимо, що з позицій синергетики стає можливим деяке нетрадиційне бачення тенденцій розвитку науки i 
культури, а також способів ефективного управління науковим прогресом. Головна проблема, мабуть, полягає в тому, як керувати, не керуючи, тобто забезпечити не кероване (ззовні), а самокерований розвиток. Сутність справи в тому, щоб дати простір для самоорганізації, щоб знання, що розвивається, саме виходило на ідеальні структури. Синергетичне бачення когнітивного світу призводить до розуміння ролі правильних, резонансних впливів для прискорення розвитку, для вибору найкоротших шляхів до нового знання й в індивідуальній творчості, і в пошукових устремліннях колективного розуму. Тільки тим відкриттям судилося вижити, отримати суспільне визнання, стати інноваціями науки й культури, які на часі й доречні, тобто $є$ резонансними за своїм хронотопом.

\section{ВИСНОВКИ}

У статті наголошено, що нове ставлення людини до світу зумовлено модернізацією культури на рубежі XX-XXI століть i процесом руйнування базових елементів культури й етичних норм. Історичний $\mathrm{i}$ сучасний досвід акультурації показує, що світ сповнений не тільки прихованої агресії й конфліктних ситуацій. Життєво важливими $є$ взаємодія та згода всіх учасників культурного діалогу. Підкреслено причини активного інтересу вчених до акультурації. Зважаючи на те що, за традицією мистецтвознавства, діалог культур розглядається здебільшого в його антропологічному аспекті, обгрунтовано можливість комплексного дослідження взаємодії через установлення міждисциплінарних зв'язків акультурації із соціологією, культурологією, психологією тощо. Удосконалено розуміння процесу акультурації.

У вузькому сенсі акультурація - це спосіб взаємозбагачення рівноправних культур, у широкому - інструментарій для модифікації соціокультурної реальності. Спираючись на культурологічний підхід на перетині філософії, історії, антропології, мовознавства, етнографії, мистецтвознавства, психології, виявили специфіку оновлення первісних смислів акультурації й особливості їі актуалізації як креативного складника простору сучасної культури.

Обгрунтовано висновок щодо значимості нових модусів процесу акультурації. Досліджено культурологічні аспекти взаємовпливу таких явищ, як соціокультурна динаміка та поява нових форм і способів буття людини в культурному просторі. Сплеск міграційної активності нині націлює культури на осмислення національних патернів i власної ідентичності.

Синергетичне бачення когнітивного світу призводить до розуміння ролі правильних, резонансних впливів для прискорення розвитку, для 
вибору найкоротших шляхів до нового знання й в індивідуальній творчості, і в пошукових устремліннях колективного розуму.

Дослідження не вичерпує коло проблемних питань, пов'язаних із необхідністю в сучасних умовах перенести акценти 3 індивіда на створення сприятливих домовленостей для розвитку української нації, а також етнічної, культурної, мовленнєвої, релігійної самобутності громадян України всіх національностей. Акцентовано увагу на нові проблеми суспільства, пов'язані з пандемією коронавірусу. У дослідженні запропоновано пріоритетні напрями модернізації громадянського суспільства.

\section{АНОТАЦІЯ}

Міжкультурний діалог подужує несприятливі аспекти глобалізації та закладає фундамент для міцного миру. Ця взаємодія визначає новий тип міжкультурного діалогу, який грунтується на культурах взаємодії, толерантності. Необхідно інтегрувати знання про особливості менталітету, соціокультурного існування та свідомості націй, етнічних, субетнічних груп і культурних регіонів. Актуальність питання викликає багатовимірність явища акультурації.

Дослідження присвячено проблемі ерозії тих етнічних культур, що відчувають масований вплив ззовні й не мають достатньо розвинутої та стійкої культурної системи, здатної протистояти культурній експансії та адекватно відповідати новим життєвим вимогам. Сьогодні у зв'язку з необхідністю реалізації заходів щодо боротьби 3 коронавірусом динаміка трансформації соціокультурної сфери, яку вона придбала в період пізньої глобалізації, може бути позитивною й отримати конструктивний розвиток: нові стилі, жанри, напрями. Але також може стати негативною й зумовити спрощення культурного життя, занепад і деградацію. Проаналізовано умови, способи реалізації процесу внутрішнього зростання в загальнолюдському масштабі.

\section{ЛІТЕРАТУРА}

1. Ракитов А.И. Культура, цивилизация и современные технологии в перспективе глобальных трансформаций. Журнальный клуб «Интелрос». Век глобализации». 2018. № 3. С. 55.

2. Лурье С. Историческая этнология : учебное пособие. Москва : Гаудеамус, 2004. 624 с.

3. Солонська Н., Борисович Г. Українська канадіана : анотований покажчик видань 3 фонду Національної бібліотеки України імені B.I. Вернадського / наук. ред. Г.І. Ковальчук ; НАН України, Нац. б-ка України ім. В.І. Вернадського. Київ, 2017. 176 с. 
4. Ясперс К. Смысл и назначение истории. Москва : Политиздат, 1991. $527 \mathrm{c}$.

5. Трощинський В. Українці у світі. Київ : Альтернативи, 1999. C. $19-24$.

6. Park R. Race and Culture. New York, 1950. C. 102.

7. Уайт Л.А. Понятие культуры / пер. Е.М. Лазаревой. Антология исследований культуры / сост. С.Я. Левит. Санкт-Петербург : Университетская книга, 1997. Т. 1. С. 17-48.

8. Хантингтон С. Столкновение цивилизаций. Москва : ООО «Издательство АСТ», 2003. С. 92.

9. Князева Е.Н. Эволюция, культура, познание. Москва, 1996. С. 78, C. 86.

10. Шейко В.М., Богуцький Ю.П., Кушнаренко Н.М. Наукова творчість у галузі культурології і мистецтвознавства : навчальний посібник. Харків : ХДАК, 2016. С. 104.

11. Пригожин И., Стенгерс И. Время, хаос, квант. К решению парадокса времени. Москва : Прогресс, 1994.

12. Князева Е.Н. Одиссея научного разума. Москва, 1995. С. 208.

Information about author:

Berezinska O. V.,

Senior Lecturer at the Department of Foreign Languages for Professional Communication,

Graduate Student at the Department of Art History and Humanitarian Disciplines International Humanitarian University 33, Fountain road str., Odessa, 65009, Ukraine 